\section{REFERENCES}

Eckstein, P., Waterhouse, J. A. H., Bond, Glenys M., Mills, W. G., Sandilands, Dorothy M., and Shotton, D. Margaret (1961). Brit. med. J., 2, 1172.

Grant, A. (1961). Med. J. Aust., 2, 936.

Greenblatt, R. B. (1958). Amer. J. Obstet. Gynec., 176, 626.

Jackson, Margaret H. (1961). Proc. roy. Soc. Med., 54, 983.

Margulis, R. R., Ladd, J. E., Fahey, M. F., and Walser, H. C. (1961). "Inhibition of Ovulation by Norethisterone Acetate," 3rd International Congress for Gynaecology and Obstetrics, Vienna.
Matsumoto, $S$, Ito, $T$, Inoue, $S$, Kuribara, $M$., and Sato, $T$. (1961). Z Zbl. Gynäk., 83, 1485 .'

Mears, Eleanor (1961). Brit. med. J., 2, 1179.

Peeters, F., van Roy, M., and Oeyen, H. (1960). Geburtsh. u. Frauenheilk., 20, 1306.

- (1961). Med. Klin., 56, 1679.

Pincus, G., Rock, J., and Garcia, C. R. (1960). Proceedings of International Conference on Planned Parenthood, New Delhi, 1959, p. 216. International Planned Parenthood Association, London.

Swyer, G. I. M. (1962). C.R. Soc. franç. Gynéc. In press.

Tyler, E. T., Olson, H. J., Wolf, L., Finkelstein, S., Thayer, J., Kaplan, N., Lewin, M., and Weintraub, J. (1961). Obstet. and Gynec., 18, 363.

\title{
PASSIVE IMMUNization AgaINST TETANUS WITH HUMAN IMMUNE GLOBULIN
}

BY

\author{
SYDNEY D. RUBBO, M.D., Ph.D., Dip.Bact. \\ Professor of Bacteriology, Department of \\ Bacteriology, University of Melbourne
}

The clinician who is called upon to treat an injured person is always confronted with the problem of specific prophylaxis against tetanus, a disease of extreme rarity but one of extreme severity should it occur. It is the latter consideration which usually dictates the management of a case, and, as a result, passive immunization with equine tetanus antitoxin is used far more often than would appear necessary or desirable. If this form of prophylaxis carried no complications then there would be little point in questioning its widespread use, but the sequelae of antiserum therapy are frequent and often disabling. Indeed, a special committee of the London Academy of Medicine, Ontario, recommended mass immunization with tetanus toxoid not to reduce the incidence of tetanus, which was negligible, but to lower the morbidity and mortality of tetanus antitoxin allergy, which was considerable (Toogood, 1960). From a review of recent papers we believe that $5-6 \%$ of persons receiving horse serum will exhibit post-injectional complications of varying severity. It is therefore understandable that there is a great reluctance to administer heterologous serum in tetanus prophylaxis.

The idea of using homologous human antitoxin has been suggested by some workers (Turner, Stafford, and Goldman, 1954; Smolens, Stokes, and Vogt, 1957 ; Stafford, 1960) but in the absence of any information on the dosage and the duration of passive immunity homologous serum has never been seriously considered. In an earlier study (Suri and Rubbo, 1961) it was shown by animal experiment that homologous serum was at least one hundred times more effective than the heterologous type. Further, it was found that a dose of 200 units of homologous antitoxin produced serum levels of $0.02 \mathrm{unit} / \mathrm{ml}$. in five out of seven persons for at least 21 days. This concentration of antitoxin, if maintained throughout the incubation period, has been estimated by Bruce (1920) to be protective.

In view of these encouraging results we have extended the above observations in order to define more precisely what antitoxin levels might be expected in humans who have been passively immunized with different doses of a purified preparation of human immune globulin. The findings, which are presented here, provide a strong case for considering the use of this preparation in relatively low doses in passive immunization against tetanus.

\author{
J. C. SURI, M.B., B.S., M.Sc. \\ Assistant Director, Central Research Institute, \\ Kasauli, Punjab
}

\section{Materials and Methods}

Twenty-seven healthy non-immune adults of European origin and six of Indian origin were passively immunized by intramuscular injection of human tetanus antitoxin. The antitoxin, which was kindly supplied to us by Dr. W. E. Ward, of Cutter Laboratories, U.S.A., was prepared from the sera of actively immunized Europeans by the Cohn ethanol fractionation procedure. It consisted of $165 \pm 15 \mathrm{mg}$. $/ \mathrm{ml}$. of $100 \%$ pure gammaglobulin, $90 \%$ of which was tetanus-immune globulin. This antitoxin, hereinafter referred to as human immune globulin, carried no risk of transmitting viral hepatitis.

All volunteers were bled (approximately $15 \mathrm{ml}$. of blood was taken) before immunization and at weekly intervals for three weeks. The antitoxin content of the sera was determined by mouse-protection tests using three mice for each serum dilution as previously described (Suri and Rubbo, 1961).

\section{Results}

In Table I the antitoxin levels for the 33 subjects are listed. The figures show remarkably little variation between different individuals receiving the same dose of antitoxin and the rate of disappearance in each dose group follows a straight-line curve. The constancy of antitoxin level and its slow die-away rate contrasts strongly with the variability found in passive immunization with heterologous serum. The only discrepancy, which was consistently observed, was the lower levels exhibited by the Indian subjects when compared with Europeans receiving the same dose of antitoxin-namely, 10 units $/ \mathrm{kg}$. of body weight. This curious difference is discussed later.

When the averages of the titrations are graphed (Fig. 1) the curves fall neatly into place in respect to dosage, and the disappearance rate is slow but constant. The Indian subjects (Fig. 2) appear to eliminate the antitoxin more rapidly, and this is consistent with the lower antitoxin levels found at the first and subsequent bleedings. In general, however, these results closely confirm our previous titrations and provide a basis for discussion of the value of human immune globulin in tetanus prophylaxis. 
TABLE I.-Serum Antitoxin Levels After Passive Immunization with Human Immune Globulin

\begin{tabular}{|c|c|c|c|c|c|}
\hline \multirow{2}{*}{$\begin{array}{l}\text { Subject } \\
\text { No. and } \\
\text { Race }\end{array}$} & \multirow{2}{*}{$\begin{array}{c}\text { Weight } \\
\text { (kg.) }\end{array}$} & \multirow{2}{*}{$\begin{array}{l}\text { Dose of } \\
\text { Tetanus } \\
\text { Antitoxin }\end{array}$} & \multicolumn{3}{|c|}{$\begin{array}{l}\text { Serum Antitoxin Level } \\
\text { (Unit ml.) at }\end{array}$} \\
\hline & & & 7 Days & 14 Days & 21 Days \\
\hline $\begin{array}{c}\text { European } \\
1 \\
2 \\
3 \\
4 \\
5 \\
6 \\
7 \\
8 \\
9\end{array}$ & $\begin{array}{l}71 \\
81 \\
67 \\
55 \\
58 \\
62 \\
58 \\
82 \\
76\end{array}$ & 5 units $\mathrm{kg}$. & $\begin{array}{l}0.07 \\
0.06 \\
0.08 \\
0.08 \\
0.07 \\
0.07 \\
0.07 \\
0.08 \\
0.05\end{array}$ & $\begin{array}{l}0.05 \\
0.06 \\
0.06 \\
0.07 \\
0.04 \\
0.05 \\
0.06 \\
0.06 \\
0.05\end{array}$ & $\begin{array}{l}0.04 \\
0.05 \\
0.06 \\
0.06 \\
0.04 \\
0.04 \\
0.04 \\
0.04 \\
0.04\end{array}$ \\
\hline Average & 68 & & 0.07 & 0.06 & 0.05 \\
\hline $\begin{array}{c}\text { European } \\
10 \\
11 \\
12 \\
13 \\
14 \\
15 \\
16 \\
17 \\
18 \\
19\end{array}$ & $\begin{array}{l}54 \\
65 \\
68 \\
52 \\
56 \\
49 \\
55 \\
60 \\
64 \\
54\end{array}$ & $7 \cdot 5$ units $\mathrm{kg}$. & $\begin{array}{l}0 \cdot 10 \\
0.08 \\
0 \cdot 11 \\
0.09 \\
0 \cdot 10 \\
0 \cdot 11 \\
0.09 \\
0 \cdot 11 \\
0 \cdot 10 \\
0 \cdot 10\end{array}$ & $\begin{array}{l}0.08 \\
0.07 \\
0.07 \\
0.07 \\
0.10 \\
0.10 \\
0.06 \\
0.10 \\
0.09 \\
0.10\end{array}$ & $\begin{array}{l}0.06 \\
0.06 \\
0.06 \\
0.06 \\
0.09 \\
0.09 \\
0.06 \\
0.09 \\
0.06 \\
0.07\end{array}$ \\
\hline Average & 58 & & $0 \cdot 10$ & 0.09 & 0.07 \\
\hline $\begin{array}{c}\text { European } \\
20 \\
21 \\
22 \\
23 \\
24 \\
25 \\
26 \\
27\end{array}$ & $\begin{array}{l}77 \\
67 \\
67 \\
67 \\
59 \\
80 \\
58 \\
59\end{array}$ & 10 units $\mathrm{kg}$. & $\begin{array}{l}0.14 \\
0.13 \\
0.12 \\
0.15 \\
0.13 \\
0.14 \\
0.14 \\
0.15\end{array}$ & $\begin{array}{l}0.12 \\
0.09 \\
0 \cdot 10 \\
0.13 \\
0 \cdot 10 \\
0 \cdot 12 \\
0.13 \\
0.13\end{array}$ & $\begin{array}{l}0.11 \\
0.08 \\
0.08 \\
0.12 \\
0.08 \\
0.08 \\
0.10 \\
0.08\end{array}$ \\
\hline Average & 67 & & $0 \cdot 14$ & $0 \cdot 12$ & 0.09 \\
\hline $\begin{array}{c}\text { Indian } \\
1 \\
2 \\
3 \\
4 \\
5 \\
6\end{array}$ & $\begin{array}{l}52 \\
61 \\
56 \\
52 \\
69 \\
50\end{array}$ & 10 units kg. & $\begin{array}{l}0.12 \\
0.10 \\
0.08 \\
0 \cdot 12 \\
0 \cdot 10 \\
0 \cdot 10\end{array}$ & $\begin{array}{l}0.06 \\
0.05 \\
0.07 \\
0.05 \\
0.05 \\
0.06\end{array}$ & $\begin{array}{l}0.03 \\
0.03 \\
0.04 \\
0.03 \\
0.03 \\
0.04\end{array}$ \\
\hline Average & 57 & & $0 \cdot 10$ & 0.06 & 0.03 \\
\hline
\end{tabular}

Pre-injection levels of serum antitoxin $<0 \cdot 002$ unit per ml. in all subjects.
DOSE

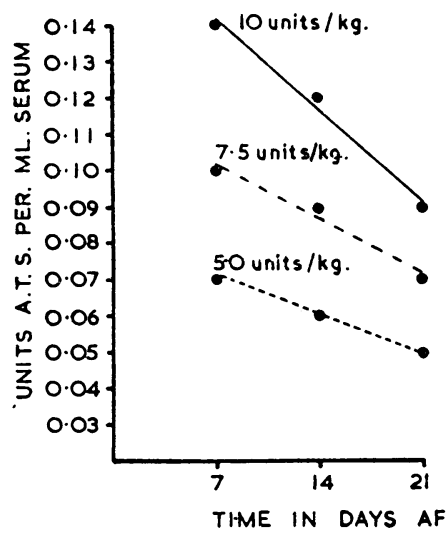

Fig. 1
SUBJECTS

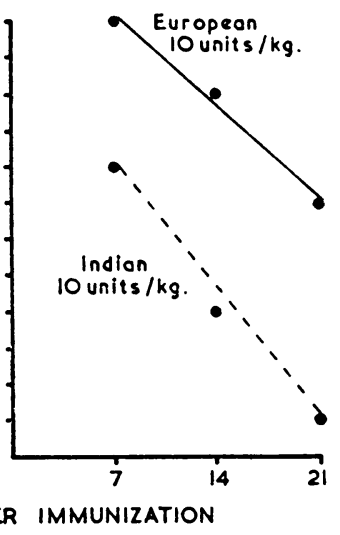

Fig. 2
Fig. 1.-Rate of disappearance of homologous tetanus antitoxin in European adults. Fig. 2.-Rate of disappearance of homologous tetanus antitoxin in European and Indian adults.

\section{Discussion}

Homologous tetanus antitoxin has three outstanding advantages over heterologous equine serum which are so significant that one must seriously question the justification for the continued use of the latter. In the first place, homologous serum does not carry any of the allergic or anaphylactic complications that are associated with the use of equine sera, however much the latter may be purified. This point is so well documented that it needs no further elaboration here. Secondly, the concentration of circulating antitoxin is predictably constant when it is used to induce passive immunity (Table I), whereas with heterologous serum antitoxin levels are variable (Suri and Rubbo, 1961). Thirdly, in contrast to heterologous antitoxin, homologous serum gives protective and persistently high levels of circulating antitoxin at much lower doses than is possible with heterologous serum. These points are now discussed in more detail.

A direct comparison of circulating antitoxin levels after passive immunization with the two types of sera has not been possible. Mainly because of ethical reasons we did not feel justified in subjecting nonimmune individuals to the risk of sensitization with equine serum. However, when the results of our previous work are compared with those reported here it is immediately obvious that a fourfold higher dose of heterologous serum fails to produce consistently a protective level of circulating antitoxin (see below) as is observed with the homologous immune globulin. The differences are shown in Table II, in which it is interesting to note that $15 \%$ of the subjects receiving the equine serum had serum antitoxin levels less than $0.05 \mathrm{unit} / \mathrm{ml}$. seven days after immunization. Variations of this type might explain the apparent failure of heterologous serum in prophylaxis and the tendency in some quarters to recommend doses as high as 3,000 units.

TABle II.-Serum Antitoxin Levels Seven Days After Passive Immunization with Tetanus Antitoxin

\begin{tabular}{|c|c|c|c|c|}
\hline \multirow{2}{*}{$\begin{array}{c}\text { Dose of } \\
\text { Tetanus } \\
\text { Antitoxin }\end{array}$} & \multirow{2}{*}{$\begin{array}{l}\text { No. of } \\
\text { Persons }\end{array}$} & \multicolumn{2}{|c|}{$\begin{array}{l}\text { No. of Persons showing } \\
\text { Antitoxin Levels }\end{array}$} & \multirow{2}{*}{ Reference } \\
\hline & & $\begin{array}{l}>0.05 \text { Unit } / \\
\text { ml. }\end{array}$ & $\begin{array}{l}<0.05 \text { Unit } \\
\text { ml. }\end{array}$ & \\
\hline $\begin{array}{l}350 \text { units human } \\
\text { immune globulin } \\
1,500 \text { units heterolo- } \\
\text { gous serum }\end{array}$ & $\begin{array}{r}9 \\
30\end{array}$ & $\begin{array}{c}9(100 \%) \\
25(85 \%)\end{array}$ & $\begin{array}{l}0 \\
5(15 \%)\end{array}$ & $\begin{array}{l}\text { Table I } \\
\text { Suri and Rubbo } \\
\text { (1961) }\end{array}$ \\
\hline
\end{tabular}

In regard to the better protective quality of homologous antitoxin this can be done directly by animal challenge experiment or indirectly by measurement of circulating antitoxin. In our previous study we were able to show in guinea-pigs that passive immunization with homologous serum was at least 100 times more effective than the heterologous serum. In fact, the differences were so profound that they suggested a qualitative rather than quantitative difference in protective capacity.

The question of dosage of homologous antitoxin necessary to confer passive protection against tetanus in man cannot be answered with certainty. In considering this question a number of factors might be taken into account, the most important of which would be: (1) the level of circulating homologous antitoxin required to protect a person during the incubation period; (2) the interference of the primary immune response to toxoid when antitoxin is given simultaneously ; and (3) the cost and availability of homologous antitoxin, preferably in the form of purified immune globulin.

In regard to the first point it is impossible to state categorically what is a protective level of homologous antitoxin in man. Bruce (1920) estimated that 0.02 unit of heterologous antitoxin per $\mathrm{ml}$. afforded protection in passive immunization. On the other hand, 0.01 unit ' $\mathrm{ml}$. is generally regarded as an adequate level in active immunization. It would not seem unreasonable to recommend 0.05 unit $/ \mathrm{ml}$. as the minimal protective con- 
centration for passively induced homologous antitoxin. From the data presented here a dose of approximately 5 units $/ \mathrm{kg}$. of body weight (350 units for an average adult) can be expected to give antitoxin levels not less than $0.05 \mathrm{unit} / \mathrm{ml}$. over a period of 14 days. Allowing for natural variation in weight among subjects and some deterioration during storage we would recommend a dose of 400 units of human immune globulin for passive immunization in adults and 200 units for children under 14.

In this connexion Smolens, Vogt, Crawford, and Stokes (1961) have carried out a similar study on the persistence of horse and human tetanus antitoxins. The general trend of their results is similar to those reported here. They showed that homologous antitoxin persisted at higher levels and for a much longer period of time than the heterologous serum. Unfortunately, we cannot compare our results with theirs, since the dose of human antitoxin they used was not clearly defined-it contained at least 500 units and less than 1,000 units $/ \mathrm{ml}$.

Whether a dose of 400 units of antitoxin will interfere with primary immune response of toxoid when given simultaneously has yet to be answered. In our earlier study we were able to show that the primary immune response to toxoid in combined active and passive immunization was best expressed by delaying the injection of toxoid for seven days or reducing the dose of antitoxin. With heterologous serum reducing the dose is contraindicated, but with homologous globulin this can be achieved without loss of passive protection. While we do not think a combined active-passive immunization treatment using $0.5 \mathrm{ml}$. of adsorbed toxoid and 400 units of human immune globulin would interfere with the primary immune response, this point will have to be established by experiment. This is now being investigated.

Finally, the question of cost and availability of immune globulin arises. This is really outside the scope of the present discussion. We realize that it could not replace equine serum on the scale at which the latter is now used, even though a much lower dosage is required. On the other hand, one might question the justification for the widespread use of passive immunization and suggest that more selective criteria should be considered. If the indications for passive immunization were based on clinical and epidemiological evidence rather than on medico-legal grounds, it is not improbable that the demand for tetanus antitoxin in general would be considerably reduced, in which case the supply of human immune globulin might come nearer to meeting the demand. For the present, however, the product should be offered at the doses recommended to all persons requiring passive immunization who are known to be hypersensitive to horse serum.

The curious but consistent difference of antitoxin levels between European and Indian subjects receiving the same dose of immune globulin must be investigated more thoroughly. At the moment we can only speculate on the reasons for the difference. For instance, the globulin used in this study was derived from Europeans, and it is possible that it is "slightly foreign" to the Indian subject and hence destroyed more rapidly. Or the protein turnover might be higher in the Indian subject because of the vast difference in protein content of the diet in the two racial groups. The phenomenon seems worthy of a more detailed investigation. These differences, however, do not detract from our demonstration that a low dose of human immune globulin is vastly superior in passive immunization against tetanus than a high sensitizing dose of horse serum.

\section{Summary}

Twenty-seven non-immune European adults and six Indians were passively immunized with tetanus antitoxin, which was given as gamma-globulin prepared from actively immunized Europeans. Titration of tetanus antitoxin in the serum of these persons was done before and 7,14 , and 21 days after immunization. The results showed that high antitoxin levels could be obtained with relatively low doses and that, in contrast to equine antitoxin immunization, the rate of disappearance of antitoxin was slow. However, the Indian subjects appeared to eliminate the immune globulin more rapidly than Europeans receiving the same dose.

The question of passive immunization using homologous antitoxin has been discussed. It is recommended that a protective dose of human immune globulin for an average adult should be 400 units and 200 units for children. These dosages will give serum antitoxin levels of not less than $0.05 \mathrm{unit} / \mathrm{ml}$. for at least 14 days in all subjects so treated. These are thought to be protective for passively induced homologous antitoxin.

We thank the Cutter Laboratories for generously supplying the human immune globulin; the director and staff of the Rijks Institute of Public Health, Utrecht, Holland, where most of the titrations were performed by one of us (J.C.S.) ; the pupils of the Ballarat Teachers' Training College, Victoria, and the staff of the General Hospital, Chandigarh, India, who served as volunteers; and Dr. A. Hill and Mr. $\mathrm{V}$. Hope for their assistance in immunizing and bleeding the subjects.

\section{REFERENCES}

Bruce, D. (1920). J. Hyg. (Lond.), 19, 1.

Smolens, J., Stokes, J., and Vogt, A. B. (1957). J. Immunol. 79, 434.

Vogt, A. B., Crawfori, M. N., and Stokes, J. (1961). J. Pediat., 59, 899 .

Stafford, E. S. (1960). J. Amer. med. Ass., 173, 539.

Suri, J. C., and Rubbo, S. D. (1961). J. Hyg. (Lond.), 59, 29.

Toogood, J. H. (1960). Canad. med. Ass. J., 82, 907.

Turner, T. B., Staftord, E. S., and Goldman, L. (1954). Bull. Johns Hopk. Hosp., 94, 204.

At the annual general meeting of the Royal Society of Tropical Medicine and Hygiene on June 21, the Society's premier honour, the Manson Medal, was awarded to Dr. Edmond Sergent of the Pasteur Institute, Algiers, already a distinguished honorary fellow of the Society. The President, Sir George McRobert, in presenting the medal, referred to Dr. Sergent's work which had proved the role of the louse as a carrier of disease, his research on the transmission of oriental sore by sandflies and his discovery that debab, the principal malady affecting camels, is caused by a trypanosome. Most, however, were familiar with his name as the originator, together with his brother Etienne Sergent, of the theory of premunition which opened up new vistas in the field of immunology. The Manson Medal is a personal award, but the President stated that he wished, on behalf of the Society, " to take this opportunity of paying tribute to France which has played such an important part in the advance of tropical medicine-in the torrid zone as a whole and in Africa in particular." Especially, he stated, " must we honour the self-sacrificing work done by generation after generation of Frenchmen in Algeria-many of them born there-commencing on the never-to-be-forgotten day, November 6, 1880, when Laveran, with the French Army in Constantine, discovered the first malaria parasite. Since that day the French in Algeria have laboured without cessation to better the lot of man and animal in Africa, and the Pasteur Institute of Algiers has shone like a beacon over darkest Africa." 